\title{
Entrepreneurial Finance in France: The Persistent Role of Banks
}

\author{
Sylvie Cieply and Marcus Dejardin
}

To be published in The Entrepreneurial Society:

How to Fill the Gap Between Knowledge and Innovation

\begin{tabular}{|l|l|}
\hline \multicolumn{2}{|l|}{ ERIM REPORT SERIES RESEARCH IN MANAGEMENT } \\
\hline ERIM Report Series reference number & ERS-2009-056-ORG \\
\hline Publication & November 2009 \\
\hline Number of pages & 17 \\
\hline Persistent paper URL & http://hdl.handle.net/1765/17430 \\
\hline Email address corresponding author & marcus.dejardin@fundp.ac.be \\
\hline Address & Erasmus Research Institute of Management (ERIM) \\
& RSM Erasmus University / Erasmus School of Economics \\
& Erasmus Universiteit Rotterdam \\
& P.O.Box 1738 \\
& 3000 DR Rotterdam, The Netherlands \\
& Phone: + 31 10 408 1182 \\
& Fax: $\quad+31104089640$ \\
& Email: info@erim.eur.nl \\
& Internet: $\quad$ www.erim.eur.nl \\
\hline
\end{tabular}

Bibliographic data and classifications of all the ERIM reports are also available on the ERIM website: www.erim.eur.nl 


\section{ERASMUS RESEARCH INSTITUTE OF MANAGEMENT}

\section{REPORT SERIES}

\section{RESEARCH IN MANAGEMENT}

\begin{tabular}{|l|l|}
\hline ABSTRACT AND KEYWORDS \\
\hline Abstract & $\begin{array}{l}\text { We study financial constraints new firms suffer from in France during the mid-nineties. Three } \\
\text { types of constraints are distinguished: the classic and well-known weak and strong credit } \\
\text { rationing and the new concept of self-rationing bound to the theory of discouraged borrowers. } \\
\text { We look for these constraints on a sample of new firms which survived at least 3 years during } \\
\text { the mid-nineties. Empirical findings show credit constraints as a whole concern 41.96\% of the } \\
\text { sample and a very low proportion of new firms suffer from credit rationing "à la Stiglitz-Weiss". } \\
\text { Weak credit rationing and self-rationing, caused by discouragement, are more widespread } \\
\text { among French new firms. We highlight moreover the role of banks during the post-start up stage } \\
\text { even if firms have suffered from credit rationing at the beginning of their life. Results not only } \\
\text { suggest the absence of firms' path of exclusion on the credit market but the rent expropriation by } \\
\text { banks. }\end{array}$ \\
\hline Free Keywords & credit rationing, self-rationing, discouragement, banks \\
\hline Availability & $\begin{array}{l}\text { The ERIM Report Series is distributed through the following platforms: } \\
\text { Academic Repository at Erasmus University (DEAR), DEAR ERIM Series Portal } \\
\text { Social Science Research Network (SSRN), SSRN ERIM Series Webpage } \\
\text { Research Papers in Economics (REPEC), REPEC ERIM Series Webpage }\end{array}$ \\
\hline Classifications & $\begin{array}{l}\text { The electronic versions of the papers in the ERIM report Series contain bibliographic metadata } \\
\text { by the following classification systems: } \\
\text { Library of Congress Classification, (LCC) LCC Webpage } \\
\text { Journal of Economic Literature, (JEL), JEL Webpage } \\
\text { ACM Computing Classification System CCS Webpage } \\
\text { Inspec Classification scheme (ICS), ICS Webpage }\end{array}$ \\
\hline
\end{tabular}




\title{
Entrepreneurial Finance in France: The Persistent Role of Banks
}

\author{
Sylvie Cieply * and Marcus Dejardin ** \\ * University of Caen, CREM-CAEN, UMR CNRS 6211, Faculty of Economics and Business Administration, \\ 19, rue Claude Bloch, 14032 Caen, Cédex, France. sylvie.cieply@unicaen.fr \\ ${ }^{* *}$ Erasmus University Rotterdam, ERIM, and FUNDP - University of Namur, CERPE \\ Corresponding address: FUNDP, Faculty of Economics, Social Sciences and Business Administration, \\ 8, Rempart de la Vierge, 5000 Namur, Belgium. marcus.dejardin@fundp.ac.be
}

November 2009

\begin{abstract}
We study financial constraints new firms suffer from in France during the mid-nineties. Three types of constraints are distinguished: the classic and well-known weak and strong credit rationing and the new concept of self-rationing bound to the theory of discouraged borrowers. We look for these constraints on a sample of new firms which survived at least 3 years during the mid-nineties. Empirical findings show credit constraints as a whole concern $41.96 \%$ of the sample and a very low proportion of new firms suffer from credit rationing “à la Stiglitz-Weiss”. Weak credit rationing and self-rationing, caused by discouragement, are more widespread among French new firms. We highlight moreover the role of banks during the post-start up stage even if firms have suffered from credit rationing at the beginning of their life. Results not only suggest the absence of firms' path of exclusion on the credit market but the rent expropriation by banks.
\end{abstract}

Key-words: credit rationing, credit rationing, self-rationing, discouragement, banks.

Acknowledgement: The authors thank Jean Bonnet for comments on this article based on previous joint works.

To be published in The Entrepreneurial Society: How to Fill the Gap Between Knowledge and Innovation, J. Bonnet, D. Garcia and H. Van Auken, eds, Cheltenham: Edward Elgar Publishing, 2010. Copyrighted. Your download is for personal use only. 


\section{Introduction}

Since the early 1980s, scientific observers and policy practitioners have drawn attention to the role of new firms for their positive contribution to employment and to local development (Piore and Sabel, 1984; Acs and Audretsch, 1993; Loveman and Sengenberger, 1991). Small is become beautiful but small is often perceived to remain difficult to be financed. Financial constraints are indeed among the most cited impeding factors for entrepreneurial dynamics to flourish (for a review, see Parker, 2004). New firms are not profitable enough to be self-financed. Because of both informational standards and costs associated with initial public offerings, they cannot raise equity on financial markets. Those whose growth rate is not exponential are not the targets of venture capital funds or business angels. Finally, their external financing is mainly based on loans, especially banking loans.

In comparison with other creditors, banks benefit indeed from advantages in financing opaque firms, and in particular new firms. Banks are specialized in gathering private information and treating it (Freixas and Rochet, 1997) and, as they manage money and deposit accounts, they own highly strategic information on firms' receipts and expenditures and on the way firms develop themselves or not (Ruhle, 1997, Diamond and Rajan, 2001). However, credit market is not perfect and, since Turgot (1766), Smith (1776) and Keynes (1930), the idea that some firms may suffer from a lack of access to credit is widespread.

Credit gap finds a strong theoretical support in the model of Stiglitz and Weiss (1981). Due to informational asymmetries, banks do not know the risk of projects although they can observe the expected returns of projects. In this situation, prices cannot clear the market; credit is allocated with rationing and equilibrium arises with a fringe of unsatisfied borrowers. This conclusion is not accepted by all the scientific community. In particular, in the framework of De Meza and Webb (1987), banks know the return of any project if successful but not the probability of success and this situation leads to over-lending. More recently, research tends to consider the cases described by Stiglitz and Weiss (1981) and De Meza and Webb (1987) as the two polar cases of a more general model of financing new investment under asymmetric information (Boadway and Keen, 2004).

Despite any consensus does not exist from a theoretical point of view and because credit rationing could hamper small firms' growth, an extensive empirical literature deals with credit rationing and small firms. In this article, we deal with this question in the French context of 
the mid-nineties. We focus on new firms which can be supposed to suffer more than the others from credit rationing if credit rationing may exist. These firms suffer indeed from a lot of backwards. Their risk of default is high. They are short of collaterals, particularly when they are innovative. They cannot produce any track record to bankers. Their informational system is not formalized enough and can generate informational asymmetries between managers and external investors.

This paper is organized in three sections. In the first section, we introduce all kinds of credit rationing new firms can suffer from. We define classical weak and strong credit rationing and introduce the concept of self rationing based on the theory of discouraged borrowers (Levenson and Willard, 2000; Kon and Storey, 2003). In the second section, we introduce the SINE surveys on new French firms by the French National Institute of Statistics (INSEE). These surveys gather individual data on entrepreneurs and new firms and allow us to build direct measures of financial constraints. In the third section, we assess empirically the importance of credit rationing in entrepreneurship. We show that credit rationing "à la Stiglitz-Weiss” is not very widespread among new firms. However, we put into light other financial constraints that illustrate either the old theory of weak credit rationing or the new theory of discouraged borrowers. We stress the specific case of innovative start-ups and the determinant role of banking finance for new firms.

\section{Theoretical framework: the diversity of credit rationing}

In this article, we want to estimate the probability that a firm's access to credit is denied for reasons other than creditworthiness. In academic literature, we can distinguish three different kinds of credit rationing. The first two types, "weak credit rationing” and "strong credit rationing”, have been analyzed for a very long time. This typology was indeed introduced by Freimer and Gordon in 1965 and popularized by Keeton in $1979^{1}$. The last type, we name "auto-constraint" or "self-rationing", is directly linked to the recent theory of discouraged borrowers (Kon and Storey, 2003).

"Weak credit rationing” (or type I) corresponds to the situation where a borrower $i$ does not succeed in getting credit enough, at the moment $t$ (Keeton, 1979). This borrower accesses to credit but for a level of debt which is inferior to the level he desires. This rationing occurs when some applicants receive, at the ruling interest rate, smaller loans than the amount they

\footnotetext{
${ }^{1}$ For a review of the literature on credit rationing, see Baltensperger and Devinney (1985), Jaffee and Stiglitz (1990) and Swank (1996).
} 
desire. Many reasons can justify this situation. The first reason, mentioned by the tenants of disequilibrium credit theory, is the rigidity of prices on the credit market which hampers the clearing of this market. Prices can be rigid because of laws on ceiling rates. The potential negative influence of these laws was mentioned very early by Turgot (1766). We must note that, in France, laws on ceiling rates have been abolished for firms, except for overdrafts, since 2005. Prices can be rigid as well because of some commercial practices. Jaffee and Modigliani (1969) and Cukierman (1978) stressed the commercial habit which consists in charging a single interest rate to a class of heterogeneous borrowers. With the increasing use of internal models of credit risk, this commercial practice is surely now obsolete; the determination of prices and non prices conditions are based on the individual analysis of risk. However, the high level of competition among banks in quite all developed countries can limit the flexibility of interest rates below the equilibrium interest rate and can give a new reality to this argument of price rigidity on credit market. The second reason why firms cannot get the quantity of credit they want is the existence of bankruptcy costs which increase with the size of credit (Jaffee and Russel, 1976). Because bigger loans involve higher repayments, they are associated with more defaults and it can be rational for bankers to cap loan size in order to limit risks of defaults. In this article, we consider that creditworthy firms suffer from a weak credit rationing if they ask for banking loan, get acceptance for it but do not get enough credit.

“Strong credit rationing” (or type II) occurs when some borrowers’ demands are turned down by banks although these borrowers are ready to pay all prices and non prices elements of the loan contract and whereas apparently identical demands are accepted by banks. In this situation, a customer $i$ does not receive at moment $t$ credit at all although a customer $j$, which does not differ apparently from $i$, gets it. This situation was first described by Stiglitz and Weiss (1981). It is due to informational asymmetries which can cause adverse selection and moral hazard. In these situations, changes in interest rates cannot restore market equilibrium and lenders, being unable to influence price levels effectively, may prefer influence quantity and limit, rationally and independently of the regulatory context, the amount of credit. Williamson (1986) confirms the existence of credit rationing, though using rather different arguments. In Williamson's view, on a market where information is imperfect, lenders must cope with opportunistic behaviors of borrowers though costly monitoring devices. When costs of monitoring exceed expected benefits, lenders prefer not to lend. In this article, we consider 
that creditworthy firms suffer from a strong credit rationing if they ask for banking loan and are denied for it.

The two precedent approaches are static. They consider the case of firms which are unable to get access to credit, partially or completely, at time $t$. Levenson and Willard (2000) and Kon and Storey (2003) question the duration of this situation and introduce a new kind of credit rationing called “discouraged borrowers”. Kon and Storey (2003) define discouraged borrowers as good firms requiring finance, which choose not to apply to the bank because they feel their application will be rejected. Levenson and Willard (2000) explain why this kind of rationing may exist: if the firm receives the credit after waiting a period of length $\alpha$ and if $\alpha$ is very small, then the firm is rationed for only a short period of time and the effects of credit rationing may be negligible. If $\alpha$ is large, then the delay to get access to credit can affect the firm's ability to expand or even survive and finally some firms that anticipate a large $\alpha$ may be discouraged from applying for credit. In this case, firms do not ask for credit at all as they anticipate the refusals of banks for a rather long period: they are self rationed. In this article, we consider that firms are self-constrained (type III) if they do not ask for banking loan although they should have asked for it as their financial needs illustrate it.

\section{The data}

For this article, we exploit information contained in the SINE dataset. This dataset allows the description of the financing policy of young firms when they are created and for the two years following the beginning of their activities. The SINE dataset does not refer to the general entrepreneurial intention within the French population but to entrepreneurial projects that are concretized in new firms. As a consequence, entrepreneurial intentions that are aborted due to financial constraints are not reported. The point is of importance as the firm financing conditions are considered.

The survey (Sine 94-1) was conducted by the French National Institute of Statistical and Economic Studies ${ }^{2}$ in 1994 and takes into account 30778 firms which had been set-up or taken over during the first half of 1994 and which had survived at least for one month. The sample $^{3}$ is originally representative of the total population of entrepreneurs which was of

\footnotetext{
${ }^{2}$ Insee (Institut National des Statistiques et des Etudes Economiques).

${ }^{3}$ The sample was built by randomly drawing out samples from the 416 (2x8x26) elementary strata. These strata are classified according to the origin (start-up or takeover: 2 modalities), the branch (8 modalities) and the localization (22 French regions plus 4 overseas départements). The dataset must then be used with the correction of a weight variable (the reverse of the draw rate per branch, per region and per origin).
} 
96407 new firms (it is a compulsory survey which obtained a $98.8 \%$ rate of reply). In this survey, new firms are identified on the basis of their registration in the "Système d'Informations et de Répertoire des Entreprises et des Etablissements” (SIRENE repertory ${ }^{4}$ ). The units, under review, belong to the private productive sector in the fields of industry, building, trade and services. The survey contains variables related to the entrepreneur and to the context of entrepreneurship.

Some questions appreciate the access of new firms to banking loans. In particular, we know first if firms ask for credit at the beginning of their life or not and second if credit is granted or denied. Thanks to the answers to these two questions, we can identify strong credit rationing which occurs when creditworthy firms asking for credit are denied. However, when credit is granted, we do not know if the quantity offered corresponds exactly to the quantity firms desire or not. Quite symmetrically, when firms don’t ask for credit, we do not know if they are self-constrained or if they really have no financial need. To come near this information, we consider the second survey carried out in 1997 (Sine 94-2). This survey gives information about the status of the same firms (closed down or still running). For the firms that are still running, this survey also explores the financial behavior of the firm during the last two years and the financial problems they faced. On the basis of this second survey, we construct classes of credit rationing. For a more appropriate homogeneity of our data basis we consider only new firms without legal change (firms which are transformed from sole proprietorship into limited partnership), set up by a man or a woman (without subsidiaries) in the metropole area (overseas department excluded). At this stage we obtain 12681 units which represent 36509 firms.

With this second survey, we know if firms have to cope with financial problems during 1996-1997. Financial problems in the post start-up stage reveal either a lack of access to funding at the beginning of their life either unanticipated financial needs. Whatever may be the reasons of the problem, this situation translates a financial constraint for firms. If firms asked at the beginning of their life for credit and got it but still faced financial difficulties in the post start-up stage, we identify a weak credit constraint which is an (imperfect) proxy of the weak credit rationing. If firms did not ask for credit at the beginning and faced financial

\footnotetext{
4 Yet economic "activations" and "reactivations" are excluded from the surveyed sample. Economic "activations" correspond to units which do not have any activity and which decide afterwards to exercise one. Economic "reactivations" correspond to units which had stopped their activity and which start up again. They only deal with individual entrepreneurs. Financial and agricultural activities and the French units established abroad are set aside as well.
} 
difficulties in the post start-up stage, we identify a self credit constraint which is a proxy for the self credit rationing.

Finally, the variable "financial constraints" that is proposed includes four modalities:

1. The modality "No rationing" is compounded of two kinds of firms. The first ones asked for banking loan and got acceptance for it. The second ones did not ask for banking loan and did not face financial problems during 1996-1997.

2. The modality "Weak constraint" groups together firms that did ask for banking loan and got acceptance for it but they faced financial problems during 19961997.

3. The modality "Strong rationing" gathers firms that did ask for banking loan and were refused for it in 1994.

4. The modality "Self constraint" concerns firms that did not ask for banking loan but should have asked for it as they faced financial constraints during 19961997.

Because of the lack of information about the building of the credit rationing variable, the data basis is now restrained to 12231 units which represent 35115 firms. At the end we consider only firms which have invested during the last two years. The sample is now restricted to 26622 firms.

To go further in analyzing self-constraint, we study the nature of relationships between banks and new firms during the post start-up stage. In Kon and Storey (2003), borrowers do not ask for credit at moment $t$ as they anticipate a large delay before being able to access to banking loan. To study the duration of credit rationing, we analyze the access of new firms to banking loan during the post start-up stage when they do not ask for credit at the beginning and when they ask for it but were denied. We compare relationships with banks with relationships with other investors, in particular proximity investors ("family, friends and fools” - the 3 F - according to Ang (1991), outsiders and other firms. The variables that are representative for financial relationships are constructed with the combination of several questions from the 1997 survey regarding the financial management policy of the cash requirement and the financial management policy of the investments and the inter-firm financial cooperation links in 1994. 
Concerning financial relationships, four dummy variables are constructed:

1. The first one is "high intensive relationships" with banks. Firms in this class manage cash requirement by overdrafts or banking loans and/or finance investments by banking loans.

2. The second one is "high intensive relationships" with " $3 F$ " or proximity finance. Firms in this class manage their cash requirement and finance their investments by private resources (from managers, relatives and/or existing associates).

3. The third dummy variable is "high intensive relationships" with external finance providers. Firms manage their requirement and/or finance their investment by raising new equities.

4. The last dummy variable is about financial links between enterprises (high intensive relationships with other firms). Strong financial links of cooperation with other firms are identified in 1994 and firms manage financial difficulties during 1996-1997 by increasing terms of payments.

In order to identify financial constraint, we need to work only with creditworthy firms. This aim is here achieved by considering the situation of firms which were established in 1994 and which were still alive in 1997. This methodological approach allows us not to consider as rationed firms that were "lame ducks" and that were identified as bad firms by bankers. A good discrimination process, which consists not to lend to bad firms (firms that will quickly die), must not indeed be considered as a rationing process. That is, some selection bias may occur as we consider only firms that were effectively created and still alive after two years of activities. Note however that, although rationed firms represent $5.20 \%$ of the firms that ceased their activities before 1997, they represent $3.26 \%$ of the firms that are still alive in 1997.

Moreover, we consider not only the global sample of firms but the sub-sample of innovative firms too. Innovative firms are the ones which belong to the classification of innovative branches given by the OECD and used in the French system of statistics (cf. Appendix). Their financial situation is specifically analyzed as all informational problems and risk exposure for lenders are more acute when borrowers are innovative; we so expect credit rationing to be more sensitive on this sub-sample. 


\section{Results}

To study the importance of financial constraints and the nature of financial relationships new firms develop with banks, we refer to descriptive and contingent analysis of the results we obtain for the modalities of the variable "financial constraint" and for the four variables that describe the nature of financial relationships.

In the following table (Table 1), we observe that $58.04 \%$ of our sample does not suffer from any financial constraint; less than the half of the sample (41.96\%) feel indeed financially rationed. When firms suffer from financial constraints, we show the diversity of credit rationing. Strong credit rationing only concern $3.64 \%$ of the sample whereas $16.02 \%$ of firms suffer from a weak credit rationing and $22.30 \%$ are self-constrained. Finally, we must note that strong credit rationing is not highly widespread among firms still alive in 1997. The most important constraint surviving new firms suffer from is self-constraint.

These results are kept when only innovative sectors are taken into account, represented by 972 firms in our sample. 44.14\% of the sample are concerned with credit rationing. At this global level, the situation of innovative firms appears to be very similar to the situation of all new firms. When we distinguish among banking constraints, we observe that, with significance, strong rationing is higher for innovative firms (5.97\%) whereas the weak rationing is less developed (8.64\%). Self constraint is more important for innovative firms (29.53\%) than for non-innovative ones. According to this result, the proportion of discouraged borrowers is higher in innovative sectors than in non-innovative ones. 
Table 1: Cross table of credit rationing in the population of firms still living in 1997

\begin{tabular}{|c|c|c|c|c|}
\hline & & \\
\hline & & $\begin{array}{l}\text { No } \\
\text { innovative }\end{array}$ & Innovative & Total \\
\hline \multirow[t]{6}{*}{$\begin{array}{l}\text { Frequency } \\
\text { Cell Chi-Square } \\
\text { Percent } \\
\text { Row percent } \\
\text { Col percent }\end{array}$} & No credit rationing & $\begin{array}{l}14909 \\
0.0301 \\
56.00 \\
96.49 \\
58.12\end{array}$ & $\begin{array}{l}543 \\
0.7944 \\
2.04 \\
3.51 \\
55.86\end{array}$ & $\begin{array}{l}15452 \\
58.04\end{array}$ \\
\hline & Self constraint & \begin{tabular}{|l|}
5649 \\
0.8634 \\
21.22 \\
95.17 \\
22.02
\end{tabular} & \begin{tabular}{|l|}
287 \\
22.783 \\
1.08 \\
4.83 \\
29.53
\end{tabular} & $\begin{array}{l}5936 \\
22.30\end{array}$ \\
\hline & Weak constraint & $\begin{array}{l}4181 \\
1.251 \\
15.71 \\
98.03 \\
16.30\end{array}$ & \begin{tabular}{|l|}
84 \\
33.032 \\
0.32 \\
1.97 \\
8.64
\end{tabular} & $\begin{array}{l}4265 \\
16.02\end{array}$ \\
\hline & Strong rationing & \begin{tabular}{|l|}
911 \\
0.5481 \\
3.42 \\
94.01 \\
3.55
\end{tabular} & \begin{tabular}{|l|}
58 \\
14.463 \\
0.22 \\
5.99 \\
5.97
\end{tabular} & $\begin{array}{l}969 \\
3.64\end{array}$ \\
\hline & Total & $\begin{array}{l}25650 \\
96.35 \\
\end{array}$ & $\begin{array}{l}972 \\
3.65 \\
\end{array}$ & $\begin{array}{l}26622 \\
100.00 \\
\end{array}$ \\
\hline & \multicolumn{4}{|l|}{$\begin{array}{l}3 \text { degrees of freedom } \\
\mathrm{Pb}(\text { Chi2 }>73.76=0.00)\end{array}$} \\
\hline
\end{tabular}

The table 2 underlines the importance of banking relationships in financing the growth of new firms. $76.79 \%$ of new firms manage with banks their financial problems in their post start-up stage. The role of other providers of finance, proximity investors (owner, his family, friend and associates), outsiders and other firms is less important. For external finance providers and other firms, this role is quite insignificant; $3.46 \%$ of our sample develops high intensive relationship with them taken together. According to Kremp (1998), Kremp and Sevestre (2000) and Cayssals, Kremp and Peter (2007), we should have expected a more important role of other firms in financing new firms. The cited literature shows indeed the increasing role of groups in France and the role of non financial firms in capital structure. On a sample of very young firms (less than 3 years), we do not observe this situation which may concern well established small and medium sized firms or subsidiaries. 
Table 2: Table of financial relationships in the population of firms still living in 1997

\begin{tabular}{|c|c|c|c|c|}
\hline & & & \\
\hline & & No Innovative & Innovative & Total \\
\hline \multirow[t]{2}{*}{$\begin{array}{l}\text { Observed Frequency } \\
\text { Theoretical }\end{array}$} & $\begin{array}{l}\text { High intensive } \\
\text { relationships with } \\
\text { banks }\end{array}$ & $\begin{array}{l}14385 \\
14188\end{array}$ & $\begin{array}{l}341 \\
538\end{array}$ & 14726 \\
\hline & \multicolumn{4}{|c|}{$\begin{array}{l}1 \text { degree of freedom } \\
\mathrm{Pb}(0,05)(\text { Chi } 2>167,02=0.00)\end{array}$} \\
\hline \multirow[t]{2}{*}{$\begin{array}{l}\text { Observed Frequency } \\
\text { Theoretical }\end{array}$} & $\begin{array}{l}\text { High intensive } \\
\text { relationships with } 3 F\end{array}$ & $\begin{array}{l}3619 \\
3650\end{array}$ & $\begin{array}{l}168 \\
137\end{array}$ & 3787 \\
\hline & \multicolumn{4}{|c|}{$\begin{array}{l}1 \text { degree of freedom } \\
\mathrm{Pb}(0,05)(\text { Chi } 2>7,74=0.00)\end{array}$} \\
\hline \multirow[t]{2}{*}{$\begin{array}{l}\text { Observed Frequency } \\
\text { Theoretical }\end{array}$} & $\begin{array}{l}\text { High intensive } \\
\text { relationships with } \\
\text { external finance } \\
\text { providers }\end{array}$ & $\begin{array}{l}291 \\
328\end{array}$ & $\begin{array}{l}50 \\
13\end{array}$ & 341 \\
\hline & \multicolumn{4}{|c|}{$\begin{array}{l}1 \text { degree of freedom } \\
\mathrm{Pb}(0,05)(\text { Chi2 }>119,06=0.00)\end{array}$} \\
\hline \multirow[t]{2}{*}{$\begin{array}{l}\text { Observed Frequency } \\
\text { Theoretical }\end{array}$} & $\begin{array}{l}\text { High intensive } \\
\text { relationships with } \\
\text { other firms }\end{array}$ & $\begin{array}{l}264 \\
311\end{array}$ & $\begin{array}{l}58 \\
11\end{array}$ & 322 \\
\hline & \multicolumn{4}{|c|}{$\begin{array}{l}1 \text { degree of freedom } \\
\mathrm{Pb}(0,05)(\text { Chi } 2>201,33=0.00)\end{array}$} \\
\hline
\end{tabular}

Contrastingly, when we only consider innovative sectors, the frequency of high intensive banking relationships decreases whereas the frequency of high intensive relationships with proximity investors, outsiders and other firms tends to increase especially for the last two external suppliers of finance.

The correlation between the hypothesis of financial constraints and each indicator of the financial relationship are reckoned with the Chi-square test between the different level of financial constraints and banking relationships (complete sample). It can be observed (Table 3) that firms that are financed by banks in the third and the fourth years after their creation are less often classified as being not rationed. They become intensive in banking relationships, whereas, at the beginning of their life, they suffer from a credit gap. The same trend can be observed concerning the weak financial constraint and the self-constraint. Firms that suffer from a weak financial constraint appear often as being high intensive in banking relationships. Firms that constrain themselves on the credit market appear more than the average classified as developing high intensive relations with banks in the two year after their establishment. 
Table 3: Cross table of high intensive relationships with banks with credit rationing in the population of firms still living in 1997

\begin{tabular}{|c|c|c|c|c|}
\hline \multicolumn{5}{|c|}{ High intensive relationships with banks } \\
\hline & & No & Yes & Total \\
\hline \multirow[t]{6}{*}{$\begin{array}{l}\text { Frequency } \\
\text { Cell Chi-Square } \\
\text { Percent } \\
\text { Row Pct } \\
\text { Col Pct }\end{array}$} & No credit rationing & \begin{tabular}{|l|}
7885 \\
139.18 \\
29.62 \\
51.03 \\
66.28
\end{tabular} & \begin{tabular}{|l|}
7567 \\
112.43 \\
28.42 \\
48.97 \\
51.39
\end{tabular} & $\begin{array}{l}15452 \\
58.04\end{array}$ \\
\hline & Self constraint & \begin{tabular}{|l|}
2329 \\
39.45 \\
8.75 \\
39.24 \\
19.58
\end{tabular} & \begin{tabular}{|l|}
3607 \\
31.871 \\
13.55 \\
60.76 \\
24.49
\end{tabular} & $\begin{array}{l}5936 \\
22.3\end{array}$ \\
\hline & Weak constraint & \begin{tabular}{|l|}
1213 \\
251.85 \\
4.56 \\
28.44 \\
10.20
\end{tabular} & \begin{tabular}{|l|}
3052 \\
203.45 \\
11.46 \\
71.56 \\
20.73
\end{tabular} & $\begin{array}{l}4265 \\
16.02\end{array}$ \\
\hline & Strong rationing & $\begin{array}{l}469 \\
2.99 \\
1.76 \\
48.40 \\
3.94\end{array}$ & $\begin{array}{l}500 \\
2.42 \\
1.88 \\
51.60 \\
3.40\end{array}$ & $\begin{array}{l}969 \\
3.64\end{array}$ \\
\hline & Total & $\begin{array}{l}11896 \\
44.68\end{array}$ & $\begin{array}{l}14726 \\
55.32 \\
\end{array}$ & $\begin{array}{l}26622 \\
100.00\end{array}$ \\
\hline & \multicolumn{4}{|c|}{$\begin{array}{l}3 \text { degrees of freedom } \\
\mathrm{Pb}(\mathrm{Chi} 2>783,65=0.00)\end{array}$} \\
\hline
\end{tabular}

On the one hand, banking relationships in the years that follow the start of firms cannot be associated with the absence of credit rationing at the beginning of their life. This observation can underline the fact that no path of exclusion can be identified on the credit market. On the other hand, banking relationships can be associated with weak financial constraints and auto constraints. This observation can be the expression of the rent expropriation described by Sharpe (1990) and Rajan (1992). Banks can profit from their informational advantage by financing firms with relatively bad conditions but better ones than those another bank could propose to new customers.

\section{Conclusion}

In this article, we study financial constraints new firms suffer from in France during the mid-nineties. We distinguish three types of credit rationing: the well-known weak and strong 
credit rationing and a self-constraint bound to the discouragement of entrepreneurs on the credit market. We obtained two major results.

We first show that a large part of new firms are not credit constrained. In particular, the strong credit rationing hypothesis only concern $3.64 \%$ of our sample and $5.97 \%$ of the subsample of the most innovative firms. Credit rationing à la Stiglitz-Weiss (1981) is the reality of a very small proportion of new firms in France during the mid-nineties. Weak rationing concerns $16.02 \%$ of the sample and only $8.64 \%$ of the sub-sample of the most innovative firms. Finally, auto constraint is the most important financial impediment new firms have to suffer from as it concerns $22.30 \%$ of the total sample and $29.53 \%$ of the sub-sample of innovative firms. These results lead us to put the contribution of Stiglitz and Weiss into perspectives when new firms are concerned. These results support all academic backgrounds based on entrepreneurs' expectations of investors' future decisions. The new theory of credit rationing based on discouragement of entrepreneurs seems to be very realistic and promising.

Secondly, despite the existence of financial constraints when new firms want to access to banking loans, banks still remain the main provider of external finance for new firms. Interfirm finance and external finance are quite unimportant. When only innovative sectors are concerned, the frequency of high intensive relationships between new firms and these two kinds of investors tends to increase but remains at a very low level.

To conclude, all our results confirm the persistent role of banks in the financing of new firms in France during the mid-nineties. Other means of financing, like venture capital, business angels and trade credit, played a minor role in the financing of French new firms on the period. These findings minimize the hypothesis of a new firm credit gap but may support as well the general direction of public aid in France which favors guaranteeing funding granted by banks to finance riskiest firms and in particular new firms. 


\section{References}

Acs, Z. J. and D. B. Audretsch (1993), Small Firms and Entrepreneurship: A Comparison between West and East Countries, Cambridge: Cambridge University Press.

Ang, J. S. (1991), “Small Business Uniqueness and the Theory of Financial Management”, Journal of Small Business Finance, 1(2), pp. 1-13.

Baltensperger, E. and T. Devinney (1985), “Credit Rationing Theory: a Survey and Synthesis”, Journal of Institutional and Theoretical Economics, 141(4), pp. 475-502.

Boadway, R. and M. Keen (2004), "Financing New Investments under Asymmetric Information: A General Approach”, Working Papers 1017, Queen's University, Department of Economics.

Cayssials, J.-L., Kremp, E. and C. Peter (2007), “Dix années de dynamique financière des PME en France”, Bulletin de la Banque de France, 165, pp. 31-48.

Cukierman, A. (1978), "The Horizontal Integration of the Banking Firm, Credit Rationing and Monetary Policy”, Review of Economic Studies 45(1), pp. 165-178.

De Meza, D.E. and D.C. Webb (1987), “Too Much Investment: a Problem of Asymmetric Information”, Quarterly Journal of Economics, 102, pp. 281-292.

Diamond, D. and R. Rajan (2001), "Liquidity Risk, Creation and Financial Fragility: A Theory of Banking”, Journal of Political Economy, 2, pp. 287-327.

Freimer, M. and M.-J. Gordon (1965), “Why Bankers Ration Credit”, Quaterly Journal of Economics, 3, pp. 397-416.

Freixas, X. and J.-C. Rochet (1997), Microeconomics of Banking. MIT Press, Cambridge, Mass.

Jaffee, D. and F. Modigliani (1969), “A Theory and Test for Credit Rationing: Reply”. American Economic Review, 5, pp. 918-920.

Jaffee, D. and T. Russel (1976), “Imperfect Information, Uncertainty, and Credit Rationing”. Quarterly Journal of Economics, 90(4), pp. 651-666.

Jaffee, D. and J. Stiglitz (1990), “Credit Rationing”. In : B. Friedman and F. Hahn eds., Handbook of Monetary Economics, vol.2 chap.16, North Holland, Amsterdam, pp. 838-888.

Keeton, W. (1979), Equilibrium Credit Rationing, New York: Garland Press. 
Keynes, J.M. (1930), A Treatise on Money, London, in The Collected Writings of John Maynard Keynes, Volume VI, The Applied Theory of Money, New York, Cambridge University Press, 1971

Kon, Y. and D.J. Storey (2003), “A Theory of Discouraged Borrowers”, Small Business Economics, 21(1), pp. 37-49.

Kremp E. and P. Sevestre (2000), “L’appartenance à un groupe facilite le financement des enterprises”, Economie et Statistique, n³36, pp. 79-92.

Kremp, E. (1998), “Structure du capital des entreprises françaises en 1996”, Bulletin de la Banque de France, n55, pp. 81-91.

Levenson, A. and K. Willard (2000) "Do Firms Get the Financing They Want? Measuring Credit Rationing Experienced by Small Businesses in the U.S.”, Small Business Economics, 14(2), pp. 83-94.

Loveman, G. and W. Sengenberger (1991), “The Re-emergence of Small-Scale Production: An International Comparison”, Small Business Economics, 1(3), pp.1-37.

Parker, S. C. (2004), The Economics of Self-Employment and Entrepreneurship, Cambridge: Cambridge University Press.

Piore, M. J. and C. F. Sabel (1984), The Second Industrial Divide. Possibilities for Prosperity, New York: Basic Books.

Rajan, R. (1992), “Insiders and Outsiders: the Choice between Relationship and Arm's Length Debt “, Journal of Finance, 47(4), pp. 1367-1400.

Ruhle, I. (1997), “Why Banks? Microeconomic Foundation of Financial Intermediaries”, Development and Finance, 3, pp. 10-99.

Sharpe, S. (1990), “Asymmetric Information, Bank Lending and Implicit Contracts: a Stylized Model of Customer Relationship”, Journal of Finance, 45(4), pp. 1069-1087.

Smith, A. (1776), Recherche sur la nature et les causes de la richesse des nations, Tome premier, traduction française, 1881 par Germain Garnier.

Stiglitz, J.E. and A. Weiss (1981), “Credit Rationing in Markets with Imperfect Information”, American Economic Review, 71(3), pp. 349-410. 
Swank, J. (1996), “Theories of the Banking Firms: a Review of Literature”, Bulletin of Economic Research, 48(3), pp. 173-207.

Turgot, A. R. J. (1766), “Réflexions sur la formation et la distribution des richesses”, in A.R.J. Turgot, Écrits économiques, Paris, Calmann-Lévy, 1970 (préface de B. Cazes).

Williamson, S.D. (1986), “Costly Monitoring, Financial Intermediation and Equilibrium Credit Rationing”, Journal of Monetary Economics, 18(4), pp. 158-179. 


\section{Appendix: Definition of Innovative Sectors by DiGITIP-Insee}

Innovative sectors gather branches from information and communication technologies, and from the fields of pharmaceutical products, biotechnology and new materials.

The definition of branches relative to the ICT, given by the OECD, encompasses:

The branches producing information technologies: computers and other computer equipment manufacturing (NAF 300C), equipment receiving, recording or reproducing sound and image manufacturing (323Z) and hertz emitting and transmitting equipment and phoning equipment manufacturing (322 A and B), navigational equipment manufacturing, apparatuses of scientific and technical instrumentation manufacturing (332 A et B and 333Z), connector industry (313Z) and passive components and condensators manufacturing, electronic components (321 A, C and D).

The branches distributing information technologies: wholesale computers and computers' equipment; wholesale office equipment (NAF 518 G and H).

The services of information technologies: telecommunications services (NAF 642), data processing services, consulting in computer systems, software production, computer and office equipment hiring, data banks activities, computer and office equipment maintenance and fixing, other activities related to computers (NAF 72 and 713 E).

The audio-visual services: TV films production, institutional and advertising films production, movies production, technical services for TV and cinema, movies distribution, videotapes production and distribution, movies broadcasting, radio activities, TV programs production, TV programs broadcasting (921, 922 A, B, D, E and F).

The other branches encompass several sub-branches in chemistry (industrial gases production, other basic inorganic chemical products, other basic organic chemical products, basic plastic materials production and basic pharmaceutical products) (NAF 241 A, E, G, L and 244 A).

They gather branches with a significant level of innovation technology measured by the number of patent registered by technological fields according to the study "Key technologies for the French industry at the 2000 horizon”. This study published by the DiGITIP -Direction Générale de l'Industrie, des Technologies de l'Information et des Postes- has been realized on the basis of works of well known experts in their field of competencies and results of several surveys related to the innovation theme realized by Insee -Institut national des statistiques et des etudes économiques- and the DiGITIP. 


\section{Publications in the ERIM Report Series Research* in Management}

\section{ERIM Research Program: "Organizing for Performance"}

\section{9}

On the Specification of the Gravity Model of Trade: Zeros, Excess Zeros and Zero-Inflated Estimation

Martijn J. Burger, Frank G. van Oort, and Gert-Jan M. Linders

ERS-2009-003-ORG

http://hdl.handle.net/1765/14614

The Current State of Research on Networks in China's Business System

Johannes Meuer and Barbara Krug

ERS-2009-007-ORG

http://hdl.handle.net/1765/14842

Encountered Problems and Outcome Status in Nascent Entrepreneurship

A. Marco van Gelderen, B. Pankaj Patel, and A. Roy Thurik

ERS-2009-008-ORG

http://hdl.handle.net/1765/14913

The Ethics of Organizations: A Longitudinal Study of the U.S. Working Population

Muel Kaptein

ERS-2009-018-ORG

http://hdl.handle.net/1765/15405

From Symbolic to Substantive Documents: When Business Codes of Ethics Impact Unethical Behavior in the Workplace Muel Kaptein

ERS-2009-021-ORG

http://hdl.handle.net/1765/15909

Knowledge Management as a Strategic Tool to Foster Innovativeness of SMEs

Haibo Zhou, and Lorraine Uhlaner

ERS-2009-025-ORG

http://hdl.handle.net/1765/15913

Knowledge Management in the SME and its Relationship to Strategy, Family Orientation and Organization Learning Haibo Zhou, and Lorraine Uhlaner

ERS-2009-026-ORG

http://hdl.handle.net/1765/15914

Defining Respectful Leadership: What it is, how it can be measured, and another glimpse at what it is related to Niels van Quaquebeke, and Tilman Eckloff ERS-2009-027-ORG

http://hdl.handle.net/1765/15942

Blue Ocean versus Competitive Strategy: Theory and Evidence

Andrew Burke, André van Stel, and Roy Thurik

ERS-2009-030-ORG

http://hdl.handle.net/1765/16037

Pattern matching

Tony Hak and Jan Dul

ERS-2009-034-ORG

http://hdl.handle.net/1765/16203

Replication

Tony Hak and Jan Dul

ERS-2009-035-ORG

http://hdl.handle.net/1765/16204 
Theory-Building With Cases

Tony Hak and Jan Dul

ERS-2009-036-ORG

http://hdl.handle.net/1765/16205

Theory-Testing With Cases

Tony Hak and Jan Dul

ERS-2009-036-ORG

http://hdl.handle.net/1765/16206

Functional Polycentrism and Urban Network Development in the Greater South East UK: Evidence from Commuting Patterns, 1981-2001

B. de Goei, M.J. Burger, F.G van Oort, and M. Kitson

ERS-2009-038-ORG

http://hdl.handle.net/1765/16213

On the Economic Foundation of the Urban Network Paradigm: Spatial Integration, Functional Integration and Economic Complementarities within the Dutch Randstad

F.G. van Oort, M.J. Burger, and O. Raspe

ERS-2009-039-ORG

http://hdl.handle.net/1765/16214

Gender Pay Differences in the European Union: Do Higher Wages Make Up For Discrimination?

Erik Canton and Ingrid Verheul

ERS-2009-041-ORG

http://hdl.handle.net/1765/16215

What do We Know about Social Entrepreneurship: An Analysis of Empirical Research

Brigitte Hoogendoorn, Enrico Pennings, and Roy Thurik

ERS-2009-044-ORG

http://hdl.handle.net/1765/16558

Developing Innovative Competences in an Emerging Business System: New Private Enterprises in Hangzhou's Software Industry

Mark Greeven and Zhao Xiaodong

ERS-2009-045-ORG

http://hdl.handle.net/1765/16599

From Inaction to External Whistleblowing: The Influence of the Ethical Culture of Organizations on Employee Responses to Observed Wrongdoing

Muel Kaptein

ERS-2009-047-ORG

http://hdl.handle.net/1765/16600

What Turns Knowledge into Innovative Products? The Role of Entrepreneurship and Knowledge Spillovers

Joern H. Block, Roy Thurik, and Haibo Zhou

ERS-2009-049-ORG

http://hdl.handle.net/1765/16769

The X-Factor: On the Relevance of Implicit Leadership and Followership Theories for Leader-Member Exchange (LMX)

Agreement

Suzanne van Gils, Niels van Quaquebeke, and Daan van Knippenberg

ERS-2009-055-ORG

http://hdl.handle.net/1765/17429

Entrepreneurial Finance in France: The Persistent Role of Banks

Sylvie Cieply and Marcus Dejardin

ERS-2009-056-ORG

http://hdl.handle.net/1765/17430 
* A complete overview of the ERIM Report Series Research in Management: https://ep.eur.nl/handle/1765/1

ERIM Research Programs:

LIS Business Processes, Logistics and Information Systems

ORG Organizing for Performance

MKT Marketing

F\&A Finance and Accounting

STR Strategy and Entrepreneurship 